\title{
Morfometrik tubuh kambing Peranakan Ettawa pada berbagai paritas di balai Pembibitan dan Budidaya Ternak Terpadu Kabupaten Kendal
}

\section{The morphometric performance of Ettawa Grade goat in various parity in Center for Integrated Livestock Breeding and Management in Kendal Re- gency}

\author{
Dwi Purwanti *, Enny T. Setiatin, Edy Kurnianto \\ Fakultas Peternakan dan Pertanian, Universitas Diponegoro \\ Kompus. Drh. R. Soejono Koesoemowardojo-Tembalang, Semarang, 50275
}

Submitted: 7 Desember 2018, Accepted: 26 Januari 2019

\begin{abstract}
ABSTRAK: Penelitian ini dilakukan dengan tujuan untuk mengetahui hubungan antara morfometrik tubuh induk kambing Peranakan Ettawa (PE) pada paritas dan litter size yang berbeda. Materi yang digunakan adalah 47 ekor induk kambing PE. Penentuan sampel penelitian menggunakan teknik purposive sampling dengan mempertimbangkan populasi kambing PE dan sentral pembibitan. Kambing PE yang digunakan adalah induk mulai paritas 1 sampai paritas 4 dan memiliki catatan litter size yang lengkap sejak kelahiran pertama. Ukuran -ukuran tubuh induk diukur meliputi dalam dada, lebar dada, lebar pinggul, tinggi pinggul, lingkar dada, panjang badan dan tinggi pundak. Data yang diperoleh dianalisis dengan prosedur General Linear Model (GLM) dan dengan Principal Component Analysis (PCA) menggunakan program Statistycal Analysis System (SAS) Ver 6.12. Hasil penelitian menunjukkan bahwa kambing PE memiliki data yang beragam pada berbagai paritas. Ukuran tubuh yang menjadi parameter pembeda berdasarkan nilai PC 1 yaitu panjang badan dengan nilai 0,695 dan lingkar dada dengan nilai 0,530. Indeks ukuran tubuh kambing PE tidak mempengaruhi jumlah anak sekelahiran. Kesimpulan dari penelitian ini adalah panjang badan dan lingkar dada dapat digunakan sebagai parameter pembeda antar paritas. Litter size akan meningkat sejalan dengan bertambahnya paritas.
\end{abstract}

Kata kunci : Kambing Peranakan Ettawa; paritas; litter size; morfometrik tubuh.

ABSTRACT: The objective of this study was to determine the relation between morphometric of different parity and litter size in Ettawa Grade goat. The material of this study was 47 heads of Ettawa Grade goat. Purposive sampling was applied to determine sample based on population and breeding policy. The Ettawa Grade used were does from1-4 parities and having litter size records from first kidding. Morphometric characteristics measured were chest depth, chest width, hip width, hip height, heart girth, body length, and withers height. The data obtained were analyzed using General Linear Model (GLM) and Principal Component Analysis (PCA) of Statistycal Analysis System (SAS) Ver 6.12. The results showed that morphometric of Ettawa Grade goat was vary and different in various parity. The PC1 of body length and heart girth were 0.685 and 0.530 respectively, indicating the most discriminant variabel to determine the differences among parity. Body index of Ettawa Grade goat does did not affect the litter size. In conclusion, body length and heart girth can be used as the differentiation parameter among parity. Litter size will increase with increasing parity.

Keywords : Ettawa Grade goat; parity; litter size; morphometric.

*Corresponding Author: dwipurwanti068@gmail.com

DOI: 10.21776/ub.jiip.2019.029.01.03 


\section{PENDAHULUAN}

Peningkatan produktivitas ternak khususnya kambing Peranakan Ettawa (PE) sangat bergantung pada sistem reproduksi. Kelahiran anak kembar (lebih dari satu) merupakan salah satu hal yang sangat diharapkan karena dapat memberikan keuntungan dari segi ekonomi. Semakin banyak anak yang dilahirkan dalam setiap kelahiran, maka seekor induk dapat dikatakan memiliki produktivas yang tinggi dalam menghasilkan keturunan (Sutiyono, Widyawani dan Purbowati, 2006).

Kambing PE lebih menguntungkan dibandingkan dengan ternak ruminansia besar dikarenakan jarak beranak yang pendek, jumlah anak sekelahiran yang banyak, kandang yang dibutuhkan tidak terlalu luas serta perputaran modalnya lebih cepat (Sutama, 2011). Kambing PE dipilih karena memiliki beberapa keunggulan dibandingkan jenis kambing yang lain. kambing ini memiliki daya adaptasi yang baik dengan kondisi iklim dan lingkungan di Indonesia serta memiliki kemampuan reproduksi yang baik (Sutama, 2008). Kambing PE memiliki sifat prolifik yaitu suatu sifat yang mampu melahirkan anak 2-3 ekor per kelahiran. Menurut Hamdani (2015), kelahiran kembar mampu meningkatkan nilai indeks produktivitas induk. Induk dengan genetik yang unggul akan menurunkan gen tersebut pada keturunannya. Sifat prolifik dapat diturunkan kepada anak untuk meningkatkan produktivitas. Upaya peningkatan mutu genetik dan populasi ternak dapat dilakukan melalui seleksi induk.

Seleksi induk yang unggul dapat dilihat dari performans (ukuran-ukuran tubuh). Ukuran-ukuran tubuh ternak diprediksi dapat menurun kepada anak. Performans tubuh kambing PE beranak kembar akan nampak lebih besar disebabkan karena anak kembar akan membutuhkan ruang abdomen dan uterus yang lebih besar.
Lebar pinggul dan panjang badan dapat digunakan untuk mengidentifikasi sifat prolifik (Sutiyono, Widyawani dan Purbowati, 2006). Kambing yang memiliki sifat prolifik pada umumnya memiliki tubuh yang besar, pertumbuhannya cepat dan memiliki ukuran panjang badan dan tinggi pundak yang lebih besar dibandingkan dengan induk yang beranak tunggal (Zulkharnaim et al., 2016).

Tujuan dari penelitian adalah untuk mengetahui dan mengkaji hubungan antara morfometrik tubuh kambing PE terhadap litter size serta untuk mengetahui indeks ukuran tubuh (IUT) kambing PE dengan paritas dan litter size. Manfaat penelitian ini adalah didapatkan informasi mengenai ukuran-ukuran tubuh kambing PE yang berpotensi untuk melahirkan anak lebih dari satu sekelahiran sehingga dapat menjadi kriteria dalam seleksi induk.

\section{MATERI DAN METODE}

Penelitian ini dilakukan pada bulan Juli - Agustus 2018 di Balai Pembibitan dan Budidaya Ternak Terpadu Dusun Klangsen, Desa Sumberejo, Kecamatan Kaliwungu, Kabupaten Kendal. Analisis data dilakukan di Laboratorium Genetika, Pemuliaan dan Reproduksi, Fakultas Peternakan dan Pertanian, Universitas Diponegoro, Semarang.

Materi yang digunakan adalah induk kambing PE yang sudah pernah beranak sebanyak 47 ekor. Alat yang digunakan dalam penelitian adalah tongkat ukur merk "Butterfly" made in Japan dengan ketelitian $0,1 \mathrm{~cm}$ untuk mengukur tinggi pundak, panjang badan, lebar pinggul, dalam dada dan lebar dada, serta pita ukur dengan ketelitian $0,1 \mathrm{~cm}$ untuk mengukur lingkar dada.

\section{Rancangan penelitian}

Metode penelitian yang digunakan dalam penelitian adalah observasional. Lokasi penelitian dipilih secara purposive sampling yaitu mempertimbangkan popu- 
lasi kambing PE dan lokasi sebagai tempat pengembangan dan pembibitan ternak ruminansia serta kambing memenuhi kriteria penelitian. Data penelitian dilakukan dengan mengukur ukuran-ukuran tubuh ternak. Kambing PE yang digunakan memiliki catatan litter size lengkap sejak kelahiran pertama. Data yang dikumpulkan meliputi umur ternak, paritas, morfometrik tubuh, dan indeks ukuran tubuh.

\section{Prosedur penelitian}

Pengambilan data morfometrik tubuh dilakukan dengan pengamatan langsung, kambing dipilih berdasarkan umur dan paritas. Penentuan umur pada kambing dilakukan berdasarkan kondisi gigi seri. Paritas ternak diketahui melalui buku catatan reproduksi dan wawancara yang dilakukan dengan pekerja lapangan. Ternak yang dijadikan sampel merupakan ternak yang memiliki paritas lebih dari satu. Prosedur penelitian ini meliputi tahap persiapan, tahap perlakuan dan tahap analisis.

Metode pengukuran morfometrik kambing menurut Fajemilehin dan Saloko (2008) yaitu:

1. Dalam dada (Chest depth): diukur dari belakang tonjolan tulang pundak sampai ketiak kaki depan.

2. Lebar dada (Chest width): diukur dari dada kiri sampai dada kanan.

3. Lebar pinggul (Hip width): diukur menggunakan tongkat ukur mulai dari sisi terluar dari sendi paha (Sutiyono, Widyawani dan Purbowati, 2006)

4. Tinggi pinggul (Hip height): jarak yang terukur dari permukaan tanah sampai tonjolan tulang pinggul. Permukaan tanah harus rata.

5. Lingkar dada (Heart Girth): diukur dengan melingkarkan pita ukur pada dada tepatnya di belakang kaki depan.

6. Panjang badan (Body Length): diukur dari tonjolan tulang duduk dekat ekor sampai tonjolan pundak (occipital protuberance) dengan posisi kaki ternak lurus.
7. Tinggi pundak (Withers Height): diukur dari belakang gumba sampai permukaan tanah.

Menurut Khargharia et al. (2015) indek ukuran tubuh (IUT) kambing dapat diketahui dengan rumus:

IUT = Panjang Badan/ Lingkar Dada

Indeks ukuran tubuh dikategorikan menjadi 3 yaitu kurus, sedang dan gemuk. Indeks ukuran tubuh kategori gemuk berkisar antara 1,04-0,94; kategori sedang 0,930,84; dan kategori kurus 0,83-0,74.

\section{Analisis data}

Data dianalisis menggunakan prosedur General Linear Model (GLM) dan Principal Component Analysis (PCA) dengan program Statistycal Analysis System (SAS) Ver 6.12. Model linier aditif indeks ukuran tubuh dengan litter size adalah:

$$
\begin{aligned}
\text { Yij } & =\mu+\tau_{\mathrm{i}}+\varepsilon_{\mathrm{ij}} ; \mathrm{i}=(1,2,3), \text { dan } \\
\mathrm{j} & =(1,2, \ldots ., 11)
\end{aligned}
$$

Keterangan:

Yij = Pengamatan parameter pada kambing PE ke-j dari kelompok paritas ke-i.

$\mu \quad=$ Nilai tengah

$\tau_{\mathrm{i}}=$ Pengaruh kelompok paritas ke-i

$\varepsilon_{\mathrm{ij}}=$ Pengaruh galat percobaan

\section{HASIL DAN PEMBAHASAN}

\section{Hubungan paritas terhadap mor- fometrik tubuh}

Morfometrik tubuh merupakan nilai kuantitatif yang didapatkan untuk menggambarkan penampilan tubuh dari suatu ternak. Sutiyono, Widyawani dan Purbowati (2006) menyatakan ukuranukuran tubuh pada ternak setiap tahun akan mengalami pertumbuhan karena ternak akan mengalami laju pertumbuhan sejak lahir hingga mencapai dewasa tubuh. Pen- 
gukuran morfometrik tubuh berdasarkan paritas kambing Peranakan Ettawah didapatkan hasil yang disajikan pada Tabel 1 .

Hasil analisis menunjukkan bahwa ukuran dalam dada pada paritas 3 dan paritas 4 tidak berbeda nyata dengan paritas 2 , tetapi berbeda nyata $(\mathrm{P}<0,05)$ dengan paritas 1 . Menurut Sutiyono, Widyawani dan Purbowati (2006), rataan ukuran dalam dada induk kambing PE dewasa pada umur 3 tahun yaitu $\pm 30 \mathrm{~cm}$. Ukuran dalam dada paritas 1 sangat kecil dibanding dengan paritas yang lain. Hal tersebut dikarenakan pada paritas 1 masih dalam tahap pertumbuhan sehingga ukuran-ukuran tubuhnya masih bisa bertambah. Hal ini sesuai dengan pendapat Kostaman dan Sutama (2006) bahwa ternak yang baru pertama kali beranak masih dalam fase pertumbuhan sehingga asupan yang masuk ke tubuh dibagi 2 yaitu untuk pertumbuhannnya sendiri dan untuk perkembangan anak di dalam kandungan.

Tabel 1. Hasil Rataan Morfometrik Tubuh Kambing PE per Paritas

\begin{tabular}{lcccc}
\hline \multirow{2}{*}{$\begin{array}{c}\text { Morfometrik } \\
\text { Tubuh }\end{array}$} & $\begin{array}{c}1 \\
(\mathrm{n}=19)\end{array}$ & $\begin{array}{c}2 \\
(\mathrm{n}=6)\end{array}$ & $\begin{array}{c}3 \\
(\mathrm{n}=18)\end{array}$ & $\begin{array}{c}4 \\
(\mathrm{n}=4)\end{array}$ \\
\cline { 2 - 5 } & $27,82 \pm 1,24^{\mathrm{b}}$ & $29,23 \pm 1,59^{\mathrm{ab}}$ & $30,33 \pm 1,65^{\mathrm{a}}$ & $30,85 \pm 1,60^{\mathrm{a}}$ \\
\hline Dalam Dada & $16,23 \pm 1,54^{\mathrm{b}}$ & $17,59 \pm 1,31^{\mathrm{ab}}$ & $17,60 \pm 1,20^{\mathrm{ab}}$ & $18,52 \pm 0,35^{\mathrm{a}}$ \\
Lebar Dada & $17,58 \pm 1,86^{\mathrm{b}}$ & $18,55 \pm 2,14^{\mathrm{b}}$ & $18,85 \pm 1,62^{\mathrm{b}}$ & $21,23 \pm 2,04^{\mathrm{a}}$ \\
Lebar Pinggul & $75,07 \pm 2,72 \mathrm{a}$ & $76,36 \pm 2,86^{\mathrm{a}}$ & $77,29 \pm 3,62^{\mathrm{a}}$ & $78,03 \pm 2,16^{\mathrm{a}}$ \\
Tinggi Pinggul & $75,02 \pm 4,21^{\mathrm{c}}$ & $77,89 \pm 4,51^{\mathrm{bc}}$ & $81,45 \pm 3,32^{\mathrm{ab}}$ & $82,61 \pm 5,13^{\mathrm{a}}$ \\
Lingkar Dada & $64,47 \pm 3,20^{\mathrm{c}}$ & $66,91 \pm 2,26^{\mathrm{bc}}$ & $70,08 \pm 4,17^{\mathrm{b}}$ & $74,93 \pm 4,84^{\mathrm{a}}$ \\
Panjang Badan & $68,65 \pm 2,68^{\mathrm{b}}$ & $72,72 \pm 4,49^{\mathrm{a}}$ & $72,85 \pm 4,40^{\mathrm{a}}$ & $73,34 \pm 2,88^{\mathrm{a}}$ \\
Tinggi Pundak & & &
\end{tabular}

Ket : Superskrip huruf yang berbeda pada baris yang sama menandakan perbedaan yang nyata $(\mathrm{P}<0,05)$.

Lebar dada pada paritas 4 tidak berbeda nyata dengan paritas 2 dan 3 tetapi berbeda nyata $(\mathrm{P}<0,05)$ dengan paritas 1 . Besar kecilnya ukuran lebar dada dipengaruhi oleh perkembangan tulang bahu tiap individu yang berbeda-beda. Lebar dada menggambarkan pertumbuhan tulang bahu yang dipengaruhi oleh pertumbuhan tulang bahu dan rongga dada. Hal ini sesuai dengan pendapat Zulfahmi, Ramdani dan Nurmeidiansyah (2016) bahwa ukuran lebar dada dipengaruhi oleh perkembangan organ-organ dalam dan pelekatan daging pada tulang bahu, sehingga menunjukkan pertambahan ukuran lebar dada.

Analisis lebar pinggul kambing PE menunjukkan hasil paritas 4 berbeda nyata $(\mathrm{P}<0,05)$ dengan paritas 1 , paritas 2 , dan paritas 3. Kemudian hasil analisis tinggi pinggul menunjukkan bahwa rataan tinggi pinggul kambing $\mathrm{PE}$ tidak berbeda nyata pada berbagai paritas. Tulang pinggul merupakan tulang yang menyusun tulang pelvis. Semakin bertambahnya umur ternak maka pertumbuhan akan terus berlangsung. Lebar tulang pinggul berhubungan erat dengan ruang abdomen dan uterus induk. 
Hal ini sesuai dengan pendapat Sutiyono, Widyawani dan Purbowati (2006) bahwa ruang abdomen yang lebar dan luas memungkinkan tercukupinya penyediaan ruang untuk perkembangan anak yang lebih dari 1 di dalam uterus. Pelvis yang lebar akan membantu mempermudah proses partus dan dapat menekan angka kematian anak akibat distokia. Menurut Sutiyono et al. (2010) bahwa lebar pinggul memiliki korelasi dengan jumlah anak sekelahiran (lahir kembar). Pinggul yang lebar dapat berdilatasi cukup lebar dan longgar sehingga dapat dilalui oleh fetus dan ternak tidak mengalami kesulitan dalam melahirkan,

Lingkar dada pada paritas 4 tidak berbeda nyata dengan paritas 3 tetapi berbeda nyata $(\mathrm{P}<0,05)$ dengan paritas 1 dan 2 . Perubahan nilai ukuran lingkar dada dipengaruhi oleh 2 aspek yaitu pertumbuhan ukuran tulang rusuk dada dan pertumbuhan jaringan otot. Semakin bertambahnya umur, maka ukuran lingkar dada masih akan mengalami perubahan. Ukuran lingkar dada dapat digunakan untuk memperkirakan bobot badan dan dapat digunakan untuk mengestimasi besar kecilnya suatu ternak dan memiliki hubungan yang erat dengan bobot hidup ternak. Menurut Gunawan, Suwiti dan Sampurna (2016), ukuran tubuh yang paling berhubungan dengan bobot badan adalah lingkar dada. Semakin panjang tulang rusuk ternak maka akan semakin banyak jaringan otot yang melekat sehingga lingkar dada ternak akan semakin besar.

Panjang badan pada paritas 1 tidak berbeda nyata dengan paritas 2 , tetapi berbeda nyata $(\mathrm{P}<0,05)$ dengan paritas 3 dan paritas 4. Semakin bertambahnya umur ternak maka pertumbuhan tulang masih akan terus berlangsung hingga mencapai titik dewasa tubuh. Induk yang memiliki ukuran panjang badan yang panjang mengindikasikan memiliki ukuran tubuh yang luas dan memiliki ruang abdomen yang cukup luas. Menurut Sutiyono, Widyawani dan
Purbowati (2006), ukuran panjang tubuh yang panjang mampu untuk menyediakan ruang uterus yang cukup untuk pertumbuhan dan perkembangan janin yang berjumlah banyak. Salah satu parameter ukuran tubuh yang perlu diperhatikan untuk kepentingan seleksi induk atau breeding yaitu ukuran panjang badan. Zulkharnaim et al. (2016) menyatakan untuk kepentingan seleksi induk, untuk breeding perlu memperhatikan ukuran panjang badan karena induk yang prolifik kemungkinan memiliki panjang badan yang lebih besar daripada induk yang beranak tunggal.

Tinggi pundak menunjukan hasil paritas 2, paritas 3 dan paritas 4 berbeda nyata $(\mathrm{P}<0,05)$ dengan paritas 1 . Kecepatan pertumbuhan tulang pundak berlangsung dengan cepat ketika ternak memasuki fase pubertas. Menurut Victori, Purbowati dan Lestari (2016), pertumbuhan tinggi pundak dipengaruhi oleh tulang kaki yang tubuh lebih awal dari pada pertumbuhaan panjang badan dan tulang lainnya karena berkaitan dengan tulang kaki depan sebagai penyangga tubuh.

Ukuran-ukuran tubuh ternak akan terus bertambah dengan bertambahnya paritas suatu ternak. Menurut Hamdani (2013), pertumbuhan pada ternak dipengaruhi oleh umur, laju pertumbuhan ternak sangat cepat sebelum memasuki dewasa kelamin dan akan melambat setelah dewasa tubuh dan akhirnya terhenti kemudian terjadi deposit lemak pada tubuh. Kecukupan pakan merupakan kunci penting bagi pertumbuhan suatu ternak. Menurut Gunawan, Suwiti dan Sampurna (2016), faktor pakan sangat mempengaruhi pertumbuhan ternak, kekurangan nutrien pada masa pertumbuhan akan menjadi kendala besar dalam proses pertumbuhan. Nutrisi dari pakan yang dikonsumsi ternak akan digunakan oleh ternak untuk memenuhi kebutuhan metabolisme tubuh, pertumbuhan dan untuk reproduksi. Hasil Principal Component Analysis (PCA) antar paritas Kambing PE disajikan pada Tabel 2. 
Tabel 2. Hasil Principal Component Analysis antarparitas Kambing PE

\begin{tabular}{cllc}
\hline No & \multicolumn{1}{c}{ Variabel } & PC 1 & PC 2 \\
\hline 1 & Dalam dada & 0,206 & 0,159 \\
2 & Lebar dada & 0,140 & 0,101 \\
3 & Lebar pinggul & 0,227 & $-0,268$ \\
4 & Tinggi Pinggul & 0,198 & 0,097 \\
5 & Lingkar dada & 0,530 & 0,269 \\
6 & Panjang badan & 0,695 & $-0,655$ \\
7 & Tinggi pundak & 0,290 & 0,735 \\
\hline
\end{tabular}

*PC: Principal Component

Pada Tabel 2 dapat dilihat bahwa panjang badan dan lingkar dada menunjukkan angka yang besar dan bernilai positif pada PC 1, masing-masing 0,695 dan 0,530. PCA merupakan analisis dekomposisi sejumlah variabel yang dapat digunakan untuk membedakan kelompok data yang diamati. PC 1 biasanya bernilai positif, sementara nilai PC2 dan nilai PC berikutnya bervariasi, ada yang positif dan ada pula yang negatif. Nilai besar dan positif pada PC1 digunakan sebagai faktor pembeda (SAS, 1980). Nilai negatif merupakan nilai kontradiktif suatu variabel terhadap sejumlah variabel lainnya. Berdasarkan analisis PCA pada penelitian ini, panjang badan dan lingkar dada dapat digunakan sebagai parameter pembeda ukuran-ukuran tubuh kambing PE atar paritas (1 -4). Menurut Udeh dan Ogbu (2011), nilai pada PC 1 yang tertinggi dapat digunakan sebagai standar utama pembeda.

\section{Hubungan paritas terhadap litter size}

Rataan litter size pada kambing PE berdasarkan paritas didapatkan hasil yang disajikan pada Tabel 3.

Tabel 3. Rataan Litter size Kambing PE berdasarkan Paritas

\begin{tabular}{ccc}
\hline Paritas & Jumlah (ekor) & Litter size \\
\hline 1 & 18 & $1,06^{\mathrm{c}}$ \\
2 & 6 & $1,25^{\mathrm{bc}}$ \\
3 & 19 & $1,60^{\mathrm{a}}$ \\
4 & 4 & $1,38^{\mathrm{ab}}$ \\
\hline
\end{tabular}

Ket : Superskrip huruf yang berbeda pada kolom yang sama menandakan perbedaan yang nyata $(\mathrm{P}<0,05)$.

Jumlah anak sekelahiran (litter size) yang paling tinggi terdapat pada paritas 3 yaitu sebesar 1,60. Hasil tersebut sedikit lebih tinggi dibandingkan dengan penelitian Sudewo, Santosa dan Susanto (2012) yaitu rataan litter size kambing PE pada paritas 3 sebesar 1,44. Hal tersebut dikarenakan induk dengan paritas 3 berada pada kisaran umur 2,5- 3,5 tahun dimana ternak telah mencapai dewasa tubuh dan dewasa kelamin serta sistem reproduksi telah sempurna dan laju pertumbuhan telah optimum. Menurut Mahmilia et al. (2005) seiring bertambahnya paritas induk, maka sistem reproduksi akan semakin sempurna baik secara fisiologis maupun hormonal.

Paritas 1 litter size menunjukkan hasil yang paling kecil yaitu sebesar 1,06. Hasil tersebut lebih kecil jika dibandingkan dengan hasil penelitian Sudewo Santosa dan Susanto (2012) yaitu rataan litter size kambing PE pada paritas 1 sebesar 1,38. Menurut Mahmilia et al. (2005), rendahnya jumlah anak yang pertama kali dilahirkan 
tersebut dikarenakan induk masih dalam fase pertumbuhan dan sistem reproduksi belum sepenuhnya siap dan berfungsi sempurna baik secara fisiologi maupun hormonal. Sehingga pada paritas 1 induk cenderung melahirkan 1 anak, namun seiring bertambahnya paritas jumlah anak yang dihasilkan juga akan bertambah.

Sudewo, Santosa dan Susanto (2012) menyatakan semakin bertambahnya umur induk dan paritas induk maka jumlah anak sekelahiran yang dilahirkan juga akan bertambah hingga mencapai puncaknya pada paritas 6 atau pada saat induk mencapai umur 6 tahun. Jumlah anak sekelahiran (Litter size) dipengaruhi oleh paritas dan ukuran tubuh induknya. Menurut Sodiq dan Sadewo (2008), postur tubuh yang besar memberi kesempatan untuk melahirkan anak yang lebih banyak dalam sekelahiran. Faktor lain yang mempengaruhi litter size yaitu jumlah ovum yang diovulasikan, bobot induk, faktor lingkungan dan faktor genetik.

\section{Hubungan indeks ukuran tubuh (IUT) terhadap litter size}

Rataan litter size kambing PE berdasarkan indeks ukuran tubuh disajikan pada Tabel 4.

Tabel 4. Rataan Litter Size Kambing PE berdasarkan IUT

\begin{tabular}{ccc}
\hline IUT & Jumlah (ekor) & Litter size \\
\hline 1 & 10 & $1,45^{\mathrm{ab}}$ \\
2 & 34 & $1,26^{\mathrm{b}}$ \\
3 & 3 & $1,72^{\mathrm{a}}$ \\
\hline
\end{tabular}

IUT 1= kecil; IUT 2= sedang; IUT 3= besar; a,b,c;

Superskrip huruf yang berbeda pada kolom yang sama menandakan perbedaan yang nyata $(\mathrm{P}<0,05)$.

Hasil analisis pada Tabel 4 menunjukkan bahwa litter size pada IUT besar tidak berbeda nyata dengan litter size IUT kecil, tetapi berbeda nyata $(\mathrm{P}<0,05)$ dengan litter size IUT sedang. IUT besar memiliki rataan jumlah anak (litter size) yang paling banyak diantara indeks bentuk tubuh yang lain yaitu sebesar 1,72. Menurut Zulkharnaim et al. (2016), induk dengan ukuran badan yang lebih besar berpotensi untuk melahirkan anak dalam jumlah yang banyak dan memiliki sifat prolifik dibandingkan dengan induk yang berukuran tubuh kecil. Menurut Fourie et al. (2002), ternak yang memiliki indeks ukuran tubuh yang besar memiliki pertumbuhan yang lebih cepat dan ditunjang dengan pakan yang mampu memenuhi kebutuhan nutrien tubuh ternak.

IUT sedang memiliki jumlah litter size paling kecil yaitu sebesar 1,26. Besar kecilnya litter size dipengaruhi oleh banyak faktor. Ukuran tubuh induk juga memiliki peran dalam menentukan jumlah anak sekelahiran akan tetapi fakor genetik, faktor lingkungan dan jumlah paritas juga memiliki peranan yang penting dalam menentukan jumlah anak sekelahiran. Hal ini sesuai dengan pendapat Kaunang, Suyadi dan Wahjuningsih (2013) bahwa litter size dipengaruhi oleh faktor lingkungan dan faktor genetik.

\section{KESIMPULAN}

Hasil penelitian menunjukkan bahwa panjang badan dan lingkar dada dapat digunakan sebagai parameter pembeda antar paritas. Litter size dipengaruhi oleh paritas tetapi tidak dipengaruhi indeks ukuran tubuh.

\section{DAFTAR PUSTAKA}

Fajemilehin, O. K. S. dan E. Saloko. 2008. Body measurement characteristics of the West African Dwarf (WAD) Goat in deciduous forest zone of 
Southwestern Nigeria. Afr. J. Biothechnol, 7(14), 2521-2526.

Fourie, P. J., F. W. C. Neser, J. J. Oliver dan C. Van Der Westhuizen. 2002. Relationship between production performance, visual appraisal and body measurement of young Dorper rams. South African. J. Anim. Sci, 32(4), 256-262.

Gunawan, I. W., N. K. Suwiti dan P. Sampurna. 2016. Pengaruh pemberian mineral terhadap lingkar dada, panjang dan tinggi tubuh sapi Bali jantan. Buletin Vet. Udayana, 8(2), 128-134.

Hamdani, M. D. I. 2013. Hubungan antara berat badan sapi betina peranakan Ongole dan sapi persilangan pada tingkatan umur yang Berbeda terhadap ukuran dan karakteristik Ovariumnya. J. Ilmiah Peternakan Terpadu, 1(3), 37-39.

Hamdani, M. D. I. 2015. Perbandingan berat lahir, persentase jeniss kelamin anak dan sifat prolifik induk kambing Peranakan Ettawah pada paritas pertama dan kedua di Kota metro. J. Ilmiah Peternakan Terpadu. 3(4), 245-250.

Kaunang, D., Suyadi dan S. Wahjuningsih. 2013. Analisis litter size, bobot lahir dan bobot sapih hasil perkawinan kawin alami dan inseminasi buatan kambing Boer dan Peranakan Etawah (PE). J. Ilmu-ilmu Peternakan, 23(3), 41-46.

Khargharia, G., G. Kadirvel., S. Kumar., S. Doley., P.K. Bharti dan M. Das. 2015. Principal component analysis of morphological traits of Assam hill goat in Eastern Himalayan India. $J$. Anim. Plant Sci., 25(5), 1251-1258.
Kostaman, T. dan I. K. Sutama. 2006. Korelasi bobot badan induk dengan lama bunting, litter size, dan bobot lahir anak kambing Peranakan Etawah. Prosiding Seminar Nasional Teknologi Peternakan dan Veteriner. Bogor, 5-6 September 2006. Pusat Penelitian dan Pengembangan Peternakan. Hal:522-527.

Mahmilia, F., M. Doloksaribu, S. Elieser dan F. A. Pamungkas. 2005. Tingkat produktivitas induk kambing persilangan (kambing Kacang dan kambing Boer) berdasarkan total bobot lahir, total bobot sapih, litter size dan daya hidup. Seminar Nasional Teknologi Peternakan dan Veteriner. Deli Serdang, 12-13 September 2005 Loka penelitian Kambing Potong.

Rasminati, N. 2013. Grade kambing Peranakan Ettawa pada kondisi wilayah yang berbeda. Sains Peternakan, 11(1), 43-48.

SAS Institue Inc. 1990. SAS/STAT User's Guide Version 6. $4^{\text {th }}$ Edition. Volume 2. SAS Campus Drive. Cary. North California.

Sodiq, A. dan Sadewo. 2008. Reproductive performance and preweaning mortality of Peranakan Etawa goat under production system of goat farming group in Gumelar Banyumas. Anim. Prod., 10(2), 6772.

Sudewo, A. T. A., S. A. Santosa dan A. Susanto. 2012. Produktivitas kambing Peranakan Etawah berdasarkan litter size, tipe kelahiran dan mortalitas di village breeding centre kabupaten Banyumas. Prosiding Seminar Nasional Pengembangan Sumber Daya Pedesaan dan Kearifan Lokal Berkelanjutan II. Purwokerto, 27-28 November 2012. Hal: 1-7. 
Sutama, I. K. 2008. Pemanfaatan sumberdaya ternak lokal sebagai ternak perah mendukung peningkatan produksi susu nasional. Wartazoa, 18(4), 207-217.

Sutama, I. K. 2011. Inovasi teknologi mendukung pengembangan kambing perah lokal. Pengembangan Inovasi Pertanian, 4(3), 231-246.

Sutiyono, B., N. J. Widyawani dan E. Purbowati. 2006. Studi performans induk Kambing Peranakan Etawah berdasarkan jumlah anak sekelahiran di Desa Banyuringin Kecamatan Singorojo Kabupaten Kendal. Prosiding Seminar Nasional Teknologi Peternakan dan Veteriner. Bogor, 5-6 September 2006. Pusat Penelitian dan Pengembangan Peternakan. Hal:537-543.

Sutiyono, B., S. Johari, E. Kurnianto, Y. S. Ondho, Sutopo, Y. Ardian, A. Kusmuhernanda dan Darmawan. 2010. Hubungan penampilan anak domba dari berbagai tipe kelahiran. J. Ilmu-Ilmu Peternakan, 20(2), 2430 .

Udeh, I. dan C. C. Ogbu. 2011. Principal component analysis of body measurements in three strains of broiler chicken. Sci. World J., 6(2), 11-14.

Victori, A., E. Purbowati dan C. M. S. Lestari. 2016. Hubungan antara ukuranukuran tubuh dengan bobot badan kambing Peranakan Etawah jantan di kabupaten Klaten. J. Ilmu-ilmu Peternakan, 26(1), 23-28.

Zulfahmi, A., D. Ramdani dan A. A. Nurmeidiansyah. 2016. Performa induk domba lokal yang dipelihara secara semintensif di kecamatan Pamanukan kabupaten Subang. Students eJournals, 5(4), 1-15.
Zulkharnaim, J. A. Syamsu, M. I. A. Dagong, dan S. Sabile. 2016. Peningkatan mutu genetik induk dan calon induk kambing PE prolifik melalui pemanfaatan pakan kulit buah kakao. J. Aves., 10 (2), 1 -9. 